\title{
DYNAMICS OF INTELLECTUAL EFFICIENCY INDICATORS OF THE SECOND STEP PUPILS OF GENERAL SECONDARY EDUCATION AT THE ENGLISH LESSONS DURING REGULAR USE OF PHYSICAL MINUTES ${ }^{1}$ Misyura Alina, ${ }^{12}$ Vrublevskiy Eugeny \\ ${ }^{1}$ Francisk Scorina Gomel State University, Gomel, Republic of Belarus ${ }^{2}$ University of Zielona Góra, Poland
}

\begin{abstract}
s:
An important indicator of society wellbeing and state in general is the health state of school students which shows not only a real situation, but also gives the chance to predict the future. Insufficient physical activity of school students is the most serious problem exerting impact on their level of health, physical condition and the level of physical and intellectual working capacity. The last, according to many modern scientists, plays one of the key roles in assimilation of knowledge in various school objects, including also English.

Article is devoted to the relevant direction in the field of modern general secondary education: the introduction of health preserving technologies in the educational process. One of the effective forms of the organization of sports-improving studies with school students is the physical minute. The classification of physical minutes and an important study guide (which is extremely necessary in making up a complex of the physical cultural pauses and physical minutes used at the English lessons) is presented in the article. The results of the researches of small sports forms influence and improving actions in the mode of school day of the second step pupils of general secondary education on indicators of their intellectual working capacity are disclosed.

As a result of the conducted research the efficiency of the developed methodical approaches of the use of physical exercises at the English lessons with pupils of the second step of general secondary education was experimentally proved. The indicators of volume and quality of intellectual efficiency of school students of the fifth forms are investigated. Quantitative and quality indicators of intellectual efficiency of pupils at the English lessons within academic year and also the influence of physical minutes on their intellectual working capacity indicators are presented.
\end{abstract}

\footnotetext{
Keywords:

school students, pupils of the second step of general secondary education, a physical minute, sports and improving occupations, intellectual working capacity, physical culture, English.
}

Динаміка показників розумової працездатності учнів другого ступеня загальної середньої освіти на уроках англійської мови при регулярному використанні фізкультхвилинок. Важливим показником благополуччя суспільства і держави в цілому $є$ стан здоров'я школярів, яке показує не тільки реальну ситуацію, а й дає можливість прогнозувати майбутнє. Недостатня рухова активність школярів $\epsilon$ найбільш серйозною проблемою, що впливає на їх рівень здоров'я, фізичний стан і рівень фізичної i розумової працездатності. Остання, на думку багатьох сучасних вчених, відіграє одну з ключових ролей в засвоєнні знань 3 різних шкільних предметів, включаючи і англійську мову. Стаття присвячена актуальному напрямку в області сучасного загальної середньої освіти: впровадження в навчальний процес здоров'я зберігаючих технологій. Однією 3 ефективних форм організації фізкультурно-оздоровчих занять $3 і$ школярами $є$ физкультминутка. У статті подано класифікацію фізкультхвилинок, а також важливі методичні вказівки, виконання яких вкрай необхідно при складанні комплексу физкультпауз i фізкультхвилинок, використовуваних на уроках англійської мови. Розкрито результати досліджень впливу малих форм фізкультурно-оздоровчих заходів у режимі навчального дня учнів другого ступеня загальної середньої освіти на показники їх розумової працездатності.

В результаті проведеного дослідження була експериментально обгрунтовано ефективність розроблених методичних підходів використання фізичних вправ на уроках англійської мови з учнями другого ступеня загальної середньої освіти. Досліджено показники обсягу і якості розумової працездатності школярів 5-х класів. Представлені кількісні та якісні показники розумової працездатності учнів на уроках англійської мови протягом навчального року, а також вплив фізкультхвилинок на показники їх розумової працездатності.

школярі, учні другого ступеня загальної середньої освіти, фізкультхвилинки, фізкультурно-оздоровчі заняття, розумова прачездатність, фізична культура, англійська мова.

\author{
Динамика показателей умственной \\ работоспособности учащихся второй \\ ступени всеобщего среднего образования \\ на уроках английского языка при \\ регулярном использовании \\ физкультминуток.
}

Важным показателем благополучия общества и государства в целом является состояние здоровья школьников, которое показывает не только реальную ситуацию, но и дает возможность прогнозировать будущее. Недостаточная двигательная активность школьников явЛяется наиболее серьезной проблемой, оказьвающей влияние на их уровень здоровья, физическое состояние и уровень физической и умственной работоспособности. Последняя, по мнению многих современных ученьх, играет одну из ключевых ролей в усвоении знаний по различным школьным предметам, включая и английский язык.

Статья посвящена актуальному направлению в области современного всеобщего среднего образования: внедрению в учебный процесс здоровье сберегающих технологий. Одной из эффективных форм организации физкультурнооздоровительных занятий со школьниками являетсяфизкультминупка. В статьепредставлена классификация физкультминугок, а также важные методические указания, выполнение которых крайне необходимо при составлении комплекса физкультпауз и физкультминуток, используемых на уроках английского языка. Раскрыты результаты исследований влияния мальх форм физкультурно-оздоровительных мероприятий в режиме учебного дня учащихся второй ступени всеобщего среднего образования напоказатели их умственной работоспособности. В результате проведенного исследования была экспериментально обоснована эффективность разработанных методических подходов использования физических упражнений на уроках английского языка с учашимися второй ступени всеобщего среднего образования. Исследованы показатели объема и качества умственной работоспособности школьников 5-х классов. Представлены количественные и качественные показатели умственной работоспособности учащихся на уроках английского языка в течение учебного года, а также влияние физкультминугок на показатели их умственной работоспособности.

икольники, учашиеся второй ступени всеобщего среднего образования, физкультминутки, физкультурнооздоровительные занятия, умственная работоспособность, физическая культура, английский язык.

Introduction. Important indicator of wellbeing of society and state in general is the state of health of school students, which shows not only a real situation, but also gives the chance to predict the future. Modern children experience big strain, studying at school. They move a little and it is difficult for them to remain sitting on one place. Besides, the visual device tests big tension during 
the occupations too. All this undoubtedly affects the state of health of children. That the school could promote improvement of the state of health of school students inclusion of small motive loading and motive pauses is necessary during the occupations [1].

One of the effective forms of the organization of sports and improving occupations with school students is the physical minute. The problem of health minutes - fatigue removal, tranquility finding, strengthening of a backbone, feet, brushes, prevention of short-sightedness, formation of a beautiful bearing, removal of the developments of stagnation caused by long sitting at the desk, intellectual working capacity increase, etc. [4].

Physical minute is the most individualized form of the short-term sports pause used mainly for local impact on the tired group of muscles. It represents a small complex of physical exercises. This concept is treated as a short rest with sports exercises [2,3]. Physical minutes are necessary to lighten children's mood, to help to intensify breath, to strengthen blood and lymph circulation of internals and stagnant sites in the child's organism, to remove a static stress. Physical minutes positively influence analytical-synthetic activity of a brain, make active cardiovascular and respiratory systems, improve operability of nervous system. Physical minutes also help to prevent and remove intellectual exhaustion [5].

Analysis of relevant research. There are different types of physical minutes [2, 3, 4, 7, 8, 9].

1. Exercises for removal of the general or local exhaustion.

Dynamic exercises with the aim of relaxation of various groups of muscles (necks, a humeral belt, extremities and the case) to remove an excessive static stress are carried out during sports minutes.

2. Exercises for hands.

During the work with pupils of elementary grades special attention should be paid to exercises for development thinly - coordinate movements of hands.

3. Gymnastics for eyes.

The gymnastics is useful for eyes to all (and to children especially) for prevention of visual impairment. Specialists in protection of sight developed various exercises. These exercises for eyes provide the movement of an eyeball on all directions. Any use of figures and lines on which children "run" eyes.

4. Gymnastics for hearing improvement.

Work on improvement of sight positively affects also hearing. And, in turn, work on improvement of hearing makes salutary impact on organs of vision.

5. Exercises for prevention of flat-footedness.

At younger school age the flat and flattened feet meet in average at $30 \%$ of boys and $20 \%$ of girls, at the same time flattening of the left feet is observed more often than right. Complaints of the child to pains in legs always have to guard adults at rather small loadings, when walking or standing.

6. The exercises correcting a bearing.

Prevention of violations of a bearing is performed in two directions - it is a creation of optimum hygienic conditions and at the same time carrying out educational work.

7. Respiratory gymnastics.

Breathing exercises help to increase excitability of big hemispheres bark of a brain, to make active children at the lesson. All exercises are carried out in well-aired room or at an open window leaf, a window, a transom [6].

Duration of sports minutes usually is $1-5 \mathrm{~min}$. Each physical minute includes a complex from three-four correctly picked up exercises repeated 4-6 times. For such short time, it is possible to remove the general or local exhaustion, considerably improve children health.

There is a number of requirements by drawing up a complex of physical minutes:

1. Exercises have to cover big groups of muscles and remove the static stress caused by long sitting at the desk. It can be pullings up, inclinations, turns, squats, jumpings up, running on the spot. Movements by brushes: tightening, unclamping, rotation. 
2. Exercises have to be simple, interesting, available to children, be connected with the content of occupations, to have game character.

3. The complex has to consist of one two exercises repeating 4-6 times. Replacement of a complex is made at least once every two weeks.

4. The content of exercises has to depend on character and conditions of carrying out a lesson. So, after written tasks, include the movements of hands, tightening and unclamping of fingers, etc.

5. In time control and some practical lessons (work, physical culture, rhythmics, etc.) the physical minute is not carried out.

Figure 1 presents some features of the formation of minutes complexes.

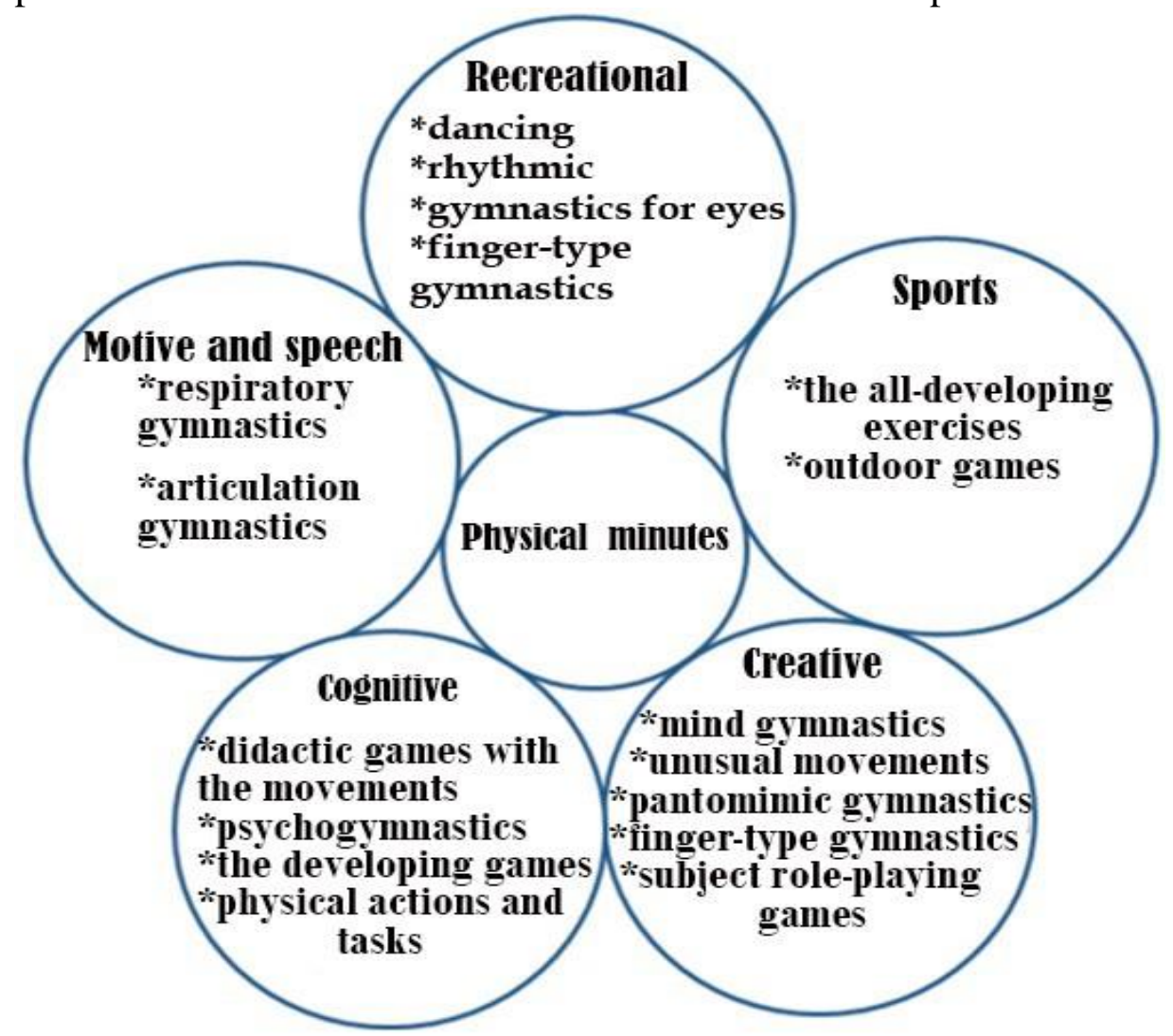

Picture 1. Peculiarities of making up physical minutes complexes

When doing physical minutes it is necessary to consider the next moments $[2,3,4,7,8,9,10$, 11]:

1. The number of sports minutes has to correspond to dynamics of efficiency of children, consider age features every year of life.

2. Complexes are selected depending on a type of a lesson, its contents. Exercises have to be various as the monotony reduces their interest, and, therefore, their effectiveness.

3. Physical minutes has to be carried out at the initial stage of exhaustion, performance of exercises at strong exhaustion does not yield desirable result.

It is important to provide a positive emotional spirit.

4. Preference needs to be given to exercises for the tired groups of muscles. For each class it is necessary to develop 2-3 conventional verbal and behavioural signs ("anchors" in terminology of neurolinguistic programming) allowing to switch quicker and more effectively than school students to other mode of activity [7].

It is not a secret for anybody that the health state of school students is one of the most important indicators of wellbeing of society and the state in general which shows not only a real situation, but also gives the chance to predict the future. 
Now children have to experience big strain, studying at school. They move a little and it is difficult for them to remain sitting on one place. Besides, the visual device tests big tension during the occupations too. All this undoubtedly affects the state of children's health $[4,5]$.

That the school could promote the improvement of the pupils' health state, it is necessary to include small motive loading and motive pauses during the occupations [10].

The introduction of health preserving technologies in educational process allows to achieve positive changes in the state of health of pupils. English is serious and one of the most difficult subjects at school. At the lessons, pupils should remember, speak, work much on grammatical material and analyze information. That's why the teacher has to pay special attention to health preserving technologies [11].

Insufficient physical activity of school students is the most serious problem exerting impact on their level of health. Authors note decrease in intellectual efficiency of pupils as during the day, and academic year in general [1-11]. The analysis of scientific and methodical literature, electronic scientific articles and magazines and also abstracts of theses for the last 7 years showed that modern scientific research does not reflect the nature of sports small forms influence and improving actions in the mode of pupil's school day.

Methods and organization of the study. During scientific research, the pedagogical experiment was made. The aim of the experiment is to define the influence of physical minutes and physical cultural pauses on the level of intellectual efficiency of school students of the 5th forms of Gomel gymnasium No. 56.

The researches were conducted from January to May, 2016. 22 pupils of the 5th forms from Gomel gymnasium No. 56 took part in them. The obtained data were processed with the use of the automated technique of assessment of intellectual efficiency of school students of "MWC" developed by E.V. Osipenko [6].

The experimental technique included carrying out of physical minutes with the pupils of 5 "A" and 5 "B" forms during the period from January to May, 2016 and from September to November, 2016. In total 399 measurements were taken. Physical minutes with the children of 5 "V" form were not carried out, however children participated in the general research of intellectual working capacity.

Regularly, during all academic year, indicators of intellectual efficiency of pupils by means of proof tables of V.Ya. Anfimov were investigated. The researches of intellectual working capacity were conducted at the beginning and at the end of a lesson and also after a physical minute in the middle of a lesson.

The results of the study and their discussion. The results of the conducted researches are presented in tables 1 and 2.

Table 1

Statistical table of proof testing intellectual efficiency results of the 5-th forms pupils at the beginning and at the end of a lesson

\begin{tabular}{|c|c|c|c|c|c|c|}
\hline \multirow{2}{*}{$\begin{array}{c}\text { Volume and quality of } \\
\text { intellectual working capacity } \\
\begin{array}{c}\text { indicators } \\
$\cline { 2 - 7 }\end{array}\end{array}} & \multicolumn{2}{|c|}{ Boys } & \multicolumn{2}{c|}{ Girls } & \multicolumn{2}{c|}{$\begin{array}{c}\mathrm{c} \text { criterion; } \mathrm{p}- \\
\text { significance value }\end{array}$} \\
\cline { 2 - 7 } & $\begin{array}{c}\text { Beginning } \\
\text { of a lesson }\end{array}$ & $\begin{array}{c}\text { End of a } \\
\text { lesson }\end{array}$ & $\begin{array}{c}\text { Beginning } \\
\text { of a lesson }\end{array}$ & $\begin{array}{c}\text { End of } \\
\text { a lesson }\end{array}$ & Boys & Girls \\
\hline 1 & 2 & 3 & 4 & 5 & 6 & 7 \\
\hline Number of works (n) & 25 & 25 & 19 & 19 & & \\
\hline The sum of the seen letters & 6653 & 7022 & 5219 & 5733 & & \\
\hline $\begin{array}{c}\text { Average quantity of the seen } \\
\text { letters (M m) }\end{array}$ & $\begin{array}{c}266,12 \pm \\
14,36\end{array}$ & $\begin{array}{c}280,88 \pm \\
16,81\end{array}$ & $\begin{array}{c}274,68 \pm \\
14,98\end{array}$ & $\begin{array}{c}301,74 \\
\pm 18,56\end{array}$ & $\begin{array}{c}\mathrm{t}=0,68 ; \\
\mathrm{p}>0,05\end{array}$ & $\begin{array}{c}\mathrm{t}=1,17 ; \\
\mathrm{p}>0,05\end{array}$ \\
\hline Mean square deviation & 70,37 & 82,36 & 63,57 & 78,76 & & \\
\hline
\end{tabular}


I І. Н А УК О В ИЙ НА ПР Я М

\begin{tabular}{|c|c|c|c|c|c|c|}
\hline \multicolumn{4}{|c|}{} & \multicolumn{1}{c|}{ Continuation of table 1 } \\
\hline $\begin{array}{c}\text { Number of works without } \\
\text { mistakes }\end{array}$ & 12 & 11 & 9 & 7 & 6 & 7 \\
\hline Sum of absolute mistakes & 21 & 30 & 15 & 31 & & \\
\hline $\begin{array}{c}\text { Average quantity of absolute } \\
\text { mistakes (M } \pm \text { m) }\end{array}$ & $0,84 \pm 0,19$ & $\begin{array}{c}1,20 \pm \\
0,29\end{array}$ & $\begin{array}{c}0,79 \pm \\
0,22\end{array}$ & $\begin{array}{c}1,63 \pm \\
0,39\end{array}$ & $\begin{array}{c}\mathrm{t}=1,06 ; \\
\mathrm{p}>0,05\end{array}$ & $\begin{array}{c}\mathrm{t}=1,92 ; \\
\mathrm{p}>0,05\end{array}$ \\
\hline Mean square deviation & 0,94 & 1,41 & 0,92 & 1,67 & & \\
\hline $\begin{array}{c}\text { Average quantity of } \\
\text { mistakes on 500 letters }\end{array}$ & 1,58 & 2,14 & 1,44 & 2,70 & & \\
\hline Efficiency of proof work (Q) & 3,17 & 2,34 & 3,48 & 1,85 & & \\
\hline
\end{tabular}

It should be noted that the volume of intellectual working capacity both at boys, and at girls of the 5th classes of Gomel gymnasium No. 56 within 2015-2016 academic years at the beginning and at the end of a lesson of English had insignificant difference towards increase in such indicators as "The sum of the seen letters" and "Average quantity of the seen letters". However, apparently from table 1 this increase which is characterized by process of a working im has also no reliable importance by Styyudent's t-criterion $(p>0,05)$. This result of the research indicates adequacy of an academic load of the 5th forms pupils of Gomel gymnasium.

It should be noted that the quality of intellectual working capacity after school considerably decreased - about 50\% on all studied indicators (see indicators: "The sum of absolute mistakes", "Average quantity of absolute mistakes" Average quantity of mistakes on 500 letters and "Efficiency of proof work (Q)") that indicates the decrease in proof work efficiency after school.

Absolutely opposite picture is observed in table 2 where the results of proof testing of intellectual efficiency of the pupils directly after carrying out physical minute at the English lessons are presented.

Table 2

Statistical table of proof testing intellectual efficiency results of the 5-th forms pupils after the carried-out physical minute

\begin{tabular}{|c|c|c|c|c|c|c|}
\hline \multirow{2}{*}{$\begin{array}{c}\text { Volume and quality of } \\
\text { intellectual working capacity } \\
\text { indicators }\end{array}$} & \multicolumn{2}{|c|}{ Boys } & \multicolumn{2}{|c|}{ Girls } & \multicolumn{2}{|c|}{$\begin{array}{l}\mathrm{t}-\mathrm{criterion} ; \mathrm{p}- \\
\text { significance value }\end{array}$} \\
\hline & $\begin{array}{l}\text { End of a } \\
\text { lesson }\end{array}$ & $\begin{array}{c}\text { After } \\
\text { phys.min }\end{array}$ & $\begin{array}{l}\text { End of a } \\
\text { lesson }\end{array}$ & $\begin{array}{c}\text { After } \\
\text { phys.min }\end{array}$ & Boys & Girls \\
\hline 1 & 2 & 3 & 4 & 5 & 6 & 7 \\
\hline Number of works (n) & 22 & 22 & 18 & 18 & & \\
\hline The sum of the seen letters & 6006 & 7740 & 5178 & 6653 & & \\
\hline $\begin{array}{l}\text { Average quantity of the seen } \\
\text { letters }(M \pm m)\end{array}$ & $\begin{array}{c}273,00 \pm \\
20,03\end{array}$ & $\begin{array}{c}351,82 \pm \\
29,77\end{array}$ & $\begin{array}{c}287,67 \pm \\
19,04\end{array}$ & $\begin{array}{c}369,61 \pm \\
18,02\end{array}$ & $\begin{array}{l}t=2,25 ; \\
p<0,05\end{array}$ & $\begin{array}{l}\mathrm{t}=3,22 \\
\mathrm{p}<0,05\end{array}$ \\
\hline Mean square deviation & 91,78 & 136,43 & 78,49 & 74,32 & & \\
\hline $\begin{array}{l}\text { Number of works without } \\
\text { mistakes }\end{array}$ & 9 & 17 & 10 & 16 & & \\
\hline Sum of absolute mistakes & 23 & 11 & 12 & 2 & & \\
\hline $\begin{array}{c}\text { Average quantity of absolute } \\
\text { mistakes }(\mathrm{M} \pm \mathrm{m})\end{array}$ & $\begin{array}{c}1,05 \pm \\
0,25\end{array}$ & $\begin{array}{c}0,50 \pm \\
0,24\end{array}$ & $\begin{array}{c}0,67 \pm \\
0,22\end{array}$ & $\begin{array}{c}0,11 \pm \\
0,08\end{array}$ & $\begin{array}{l}t=1,62 ; \\
p>0,05\end{array}$ & $\begin{array}{l}\mathrm{t}=2,45 \\
\mathrm{p}<0,05\end{array}$ \\
\hline
\end{tabular}




\section{І І. НА УК О В ИЙ НА ПР Я М}

\begin{tabular}{|c|c|c|c|c|c|c|}
\hline \multicolumn{4}{|c|}{} & \multicolumn{4}{c|}{ Continuation of table 2 } \\
\hline 1 & 2 & 3 & 4 & 5 & 6 & 7 \\
\hline Mean square deviation & 1,13 & 1,10 & 0,91 & 0,32 & & \\
\hline $\begin{array}{c}\text { Average quantity of mistakes } \\
\text { on 500 letters }\end{array}$ & 1,91 & 0,71 & 1,16 & 0,15 & & \\
\hline Efficiency of proof work (Q) & 2,61 & 4,25 & 4,32 & 8,5 & & \\
\hline
\end{tabular}

On all studied indicators characterizing both the volume, and quality of intellectual working capacity is noted considerable and authentically significant gain (by Styyudent's t-criterion $(p<0,05)$.

Especially here, we are impressed by the considerable gain of the indicators characterizing quality of intellectual working capacity. So, in the indicator "The sum of absolute mistakes" the gain made $52 \%$ - at boys and $83 \%$ is at girls. The indicator "Efficiency of proof work (Q)" proved to be in table 2 from a gain in $62,9 \%$ at boys and girls have more than $93 \%$.

Because of the conducted research, the efficiency of the developed methodical approaches of the physical exercises use at the English lessons with school students of the 5th forms was experimentally proved. The indicators of volume and quality of intellectual efficiency of the 5th forms school students are investigated. The statistical reliability of positive shifts on all studied indicators of intellectual efficiency of school students was established.

Conclusion. Thus, the organization and holding sports improving actions in a day regimen allows increasing physical activity of school students considerably, to solve a number of problems of educational character, to strengthen health, to create positive, joyful emotions which promote the increase in working capacity, successful assimilation of knowledge in the course of training in general educational objects.

The methodical approaches of the physical exercises use offered by us at the English lessons influence well on pupils' intellectual efficiency, stir up their educational activity, increase interest in the English lessons, and allow acquiring new lexicon in an interesting and available form. It allows expanding theoretical knowledge of school students about the means and methods of physical culture, to create new physical actions, to increase pupils' interest to physical training lessons.

\section{Список литературных источников:}

1. Конлпаштина здоровьесберегаюших английского языка. Злоповье - основа человеческого потеніиала: ппоблемы и пути их решения. 2014. Т. 9. № 1, C. $268-269$.

2. К Кзнешов Б.В.. Шvткин С.Н. Ипполитов В.В. Физкультминутки и физкультпаузы. как малые внеvnочные фопмы занятий физической кVльтvnой. Пожапная безопасность: ппоблемы и перспективы. 2015. T. 1. № 1 (6), C. $286-289$.

3. Мальцева А.В., Физкультминутка как

Соболева

E.A. компонент здоровьесбережения на уроке английского языка. Наука сегодня: проблемы и пути решения: матер. Межд. науч.-практ. Конф.: в 2 частях. Вологда. 2016, С. $46-47$

4. Мicюра А.А. Фізкультхвилинка як форма опганізапіï фізкультупно-озлоповчих занять зі шाколяпами. Наvка і мололь в XXI стопіччі : зб. тез доповідей III Міжн. молодіжної наvк.-практ. інтернетконференшіі. Полтава: ПУЕТ. 2017. С.474-477.

5. Мicюna А.А.. Гvсинеш С.В.. Особливості викопистання фізичних вппав на vроках англійської мови 3 учнями 5-х класів. Взаємолія луховного й фізичного виховання в становленні гапмонійно nозвиненої особистості : зб. статей за матепіалами IV Міжн. нау-ково-практичної онлайн-конференції. у 2

\section{References:}

1. Kondrashkina S.V. Use of health saving technologies at the English lessons. Health - a basis of human potential: problems and ways of their decision. 2014. T. 9. No. 1, P. $268-269$.

2. Kuznets B.V., Shutkin S.N., Ippolitov V.V. Physical minutes and physical cultural pause as small after-hour forms of work physical culture. Fire safety: problems and prospects. 2015. T. 1. No. 1 (6), P. 286 $-289$.

3. Maltseva A.V., Soboleva E.A. Physical minute as a health-saving component at the English lesson. Science today: problems and solutions: materials of the international scientific and practical conference: in 2 parts. Vologda. 2016, P. 46 - 47.

4. Misyura A.A. Physical minute as a form of sports organization and improving occupations with school students. Science and youth in 20th century: collection of theses reports of the III International youth scientific and practical Internet conference. Poltava: PUET. 2017, P. 474 - 477.

5. Misyura A.A., Gusinets E.V. Features of physical exercises use at the English lessons with pupils of the 5th forms. Interaction of spiritual and physical training in formation of harmoniously developed personality: the collection of articles on materials of the 4th Intern. Scientific and practical online conference. in 2 volumes / main edition V.M. 
томах / гол. пел. В.М. Ппистинський. Слов’янськ: ЛВН3 “Лонбаський лепжавний педагогічний університет". Т. 1. 2017. С.341-345.
6. Осипенко
E.B.

Умственная

работоспособность школьников. проживаюших в vсловиях Гомельского пегиона: монография. Гомель: ГГУ им. Ф. Скорины. 2012, 388 с.

7. Пахомова Л.Э., Фесенко А.С. Влияние физкультминуток на умственную работоспособность учащихся специальной медицинской группы. Современные тенденции развития науки и технологий. 2016. № 8, С. $120-122$.

8. Погодина, Н.А. Физкультурные минутки на уроках английского языка. Педагогический опыт: теория, методика, практика. 2014. № 1 (1), С. 329 331.

9. Физкультминутки: учебное пособие / сост. С.А. Лёвина, С.И. Тукачёва. Волгоград: Учитель. 2006, 76 c.

10. Чаплинская Ю.Г. Физкультминутка на уроках английского языка в свете новых решений о повышении физической активности школьников. Современная педагогика. 2013. № 10 (11), С. 2.

11. Шуварикова А.А. Физкультминутки - одно из средств здоровьесберегающих технологий в образовательном процессе. Проблемы развития физической культуры и спорта в новом тысячелетии. Омск. 2014. T. 1. № 1, С. $138-140$.
Pristinsky. Sloviansk: DVNZ "Donbass State Pedagogical University". 2017. T. 1, P. 341 - 345.

6. Osipenko E.V. Intellectual efficiency of the school students living in conditions of the Gomel region: monograph. Gomel: GGU of F. Skorina. 2012, $388 \mathrm{p}$.

7. Pakhomova L.E., Fesenko A.S. Physical minutes' influence on intellectual efficiency of pupils of special medical group. Current trends of development of science and technologies. 2016. No. 8, P. $120-122$.

8. Pogodina N.A. Sports minutes at the English lessons. Pedagogical experience: theory, technique, practice. 2014. No. 1 (1), P. $329-331$.

9. Physical minutes: education guidance / orig. S.A. Lyovina, S.I. Tukachyova. Volgograd: Teacher. 2006, 76 p.

10. Chaplinskaya Yu.G. Physical minute at the English lessons in the light of new decisions in the physical activity increase of school students. Modern pedagogics. 2013. No. 10 (11), P. 2.

11. Shuvarikova A.A. Physical minute - one of the means of health saving technologies in educational process. Problems of development of physical culture and sport in the new millennium. Omsk, 2014. T. 1. No. 1 , P. $138-140$.

\section{DOI: http://doi.org/10.5281/zenodo.1294618}

\section{Відомості про авторів:}

Врублевский Е. П.; orcid.org/0000-0001-5053-7090; vru-evg@yandex.ru; Учреждение образования «Полесский государственный университет», ул. Днепровской флотилии, 23, Пинск 225710, Республика Беларусь; Зеленогуский университет, ул. Licealna 9, Зелена Гура, Польша.

Мисюра А. А.; orcid.org/0000-0002-1657-1778; kabanoslik@mail.ru; Учреждение образования «Полесский государственный университет», ул. Днепровской флотилии, 23, Пинск 225710, Республика Беларусь. 